\title{
Lives as Collections of Strands: An Essay in Descriptive Psychology
}

Journal Title

$\mathrm{XX}(\mathrm{X}): 1-26$

(C)The Author(s) 2020

Reprints and permission:

sagepub.co.uk/journalsPermissions.nav

DOI: 10.1177/ToBeAssigned

www.sagepub.com/

SAGE

\section{Michael Kubovy}

\begin{abstract}
In this article I generalize the notion of multiple self-aspects to create a descriptive framework in which lives are partitioned into containers of activities called strands. Strands are nearly-decomposable life-modules, structured, stable, and concurrent longitudinal streams of extended duration whose momentary cross-sections constitute selfaspects. They are differentiated by five features: (a) the person's role, (b) the cast, (c) the setting, (d) norms and values, and (e) habits and routines. Strands contain projects, and episodes, and are replete with narrative. Each strand is continuous (i.e., strands persist when a person moves between them), and for the most part strands are mutually asynchronous. From a first-person perspective, the strands are continuous and concurrent but only one strand is in the foreground at a given time, i.e., transitions between strands are akin to a figure-ground reversal. Furthermore, a life is different from the sum of its strands: it is a nonlinear system that can take on configurations not predictable from a comprehensive description of the individual strands. Two such examples are the achievement of greatness despite severe handicaps and instances of extreme self-sacrifice. I also discuss the research potential of a proposed smartphone app called LifeMaps.
\end{abstract}

\section{Keywords}

lives, strands, nearly decomposable, aspects of self, asynchrony, nonlinearity, smartphone app

\section{introduction}

This article (which complements Kubovy, 2015), offers a descriptive framework for psychology. It rests on three propositions: (a) Modularity: From a first-person point of view, lives are approximately modular. These modules, called strands, are containers of activities. This modularity holds whether we consider a life longitudinally or at a given moment. From a longitudinal point of view, strands form a set of structured, and stable streams of related activities and episodes. At a given moment strands constitute stable and enduring aspects of the self. (b) Asynchronous concurrency: Research in perception shows that under some circumstances we perceive events alternating in time as if they were asynchronous concurrent streams. To a first approximation, this is the case with strands: when a person inhabits one strand, the person's other strands are not interrupted. Likewise, also to a first approximation, strands are asynchronous. The order of events that took place in the same strand, is much more likely to be registered than the order of events that occurred in different strands. (c) Nonlinearity: A life is different from the sum of its strands. The relation between the current and the other strands in a person's life, resembles the perceptual relation between figure and ground. The Gestalt of a life (including the person's subjective well-being) may be a nonlinear

\section{University of Virginia}

\section{Corresponding author:}

Michael Kubovy, Department of Psychology, University of Virginia, PO Box 400400 Charlottesville, VA 22904-4400

Email: kubovy@virginia.edu 
function of (i) the manner in which a person allocates time to different strands, as well as (ii) the distribution across strands of a person's satisfaction or dissatisfaction.

Before I proceed, a word about the importance of description. "Rutherford used to divide science into physics and stamp collecting," wrote Bernal (1939, p. 9, see also O'Toole, 2015). But careful and systematic description is not stamp collecting. Without it there is no science. As Grimaldi and Engel (2007) point out, biological classification is still based on Carl Linnaeus's Species Plantarum of 1753 (Ohl, 2018), the geological timescale is is derived from the maps of William Smith (2015), begun in 1799, and the periodic table, created by Dmitri Mendeleev in 1869, is alive and well (Scerri and Restrepo, 2018). In the study of the behavior of animals, including humans, Darwin's (1987) descriptive work remains a foundation of psychology, as does the ethological work of Lorenz (1937) and Tinbergen (1939), who were influenced by von Uexküll (1909). As for psychology, several important figures did descriptive work in several disciplines: Wertheimer (1912) on apparent motion, Piaget (1924) on cognitive development, Bartlett (1932) on memory, and Gibson (1950, 1986, 1979, 1966) on perception.

Despite these achievements, psychologists have rejected description as theory-free fact collecting (dismissively called "dust-bowl empiricism" by Meehl, 1956), and declared that without theory psychology could not be a science (Spence, 1944). And so psychology finds itself with a surfeit of theories (Greenwald et al., 1986) and a dearth of descriptions. ${ }^{1}$

This article is divided into two parts. In the first, I lay out the description of lives as partitioned into strands. In the second, I show how this description is consistent with well-known perceptual and cognitive phenomena.

\section{The benefits of modularized lives}

Simon $(1994,1999)$ proposed that some systems (natural or artificial) are made up of modules. In the context of lives, I call these modules strands.

In some cases, modules operate independently of each other, which makes the system completely decomposable. In other cases, although the modules are not completely independent, the interactions between them are weak, in which case the system is nearly decomposable.

Simon (1962, pp. 474-475 and Fig. 1) gives the example of a building as a nearly decomposable system. It consists of cubicles, whose walls readily conduct heat, and rooms, whose walls are good insulators. To illustrate how a nearly decomposable system evolves, suppose that at $t_{0}$ there are large temperature differences between cubicles. At a later time, $t_{1}$, the variation in temperature among cubicles will be small, but among rooms they will still be large. Eventually, at time $t_{2}$, all temperature differences within the building will have vanished.

If strands are nearly decomposable, then even when a life-event disturbs one strand (e.g., an illness, analogous to temporarily putting a space-heater in one of the cubicles), the effect on other strands is small and dissipates quickly. In the short run, changes in one strand have little effect on other strands. When something bad happens in one strand, other strands are insulated from this harm. It is also easier to improve one's situation in one strand without having to consider all the others. At the same time, if a life is nearly decomposable, then in the long run events in one strand may affect all the others, as would befit a single system.

However this description of lives as nearly decomposable is but a first approximation, because Simon's systems are linear (they are modeled by a system of linear differential equations). In linear systems, the whole is equal to the sum of its parts. In the second part of this article, we will see that this is not the case with lives, and that a collection of strands should be thought of as a nonlinear system.

Our descriptive framework starts with the notion of the self (Calkins, 1900, 1915; Curtis, 1915; Gamble, 1915; James, 1981). Over the years, for a variety of reasons, a growing group of scholars abandoned the idea of a unitary self in favor of the idea of multiple selves, multiple self-aspects, or the self as an organized system of roles (Donahue et al., 1993; Lester, 2017; Marks and MacDermid, 1996; McConnell et al., 2012; Showers and Zeigler-Hill, 2007). A similar view evolved in organization studies (particularly the work of Ashforth, 2001), and in research on organizational identity (Pratt et al., 2016). Our description takes the notion of multiple selves and generalizes it into the longitudinal structures I call strands. 
Strands may be characterized in two ways: by features that differentiate each from the others, and by features they all share. Although one might want to know first what features they share, these features are rather abstract, and not easy to understand without concrete examples. On the other hand, the differences between them are concrete and easy to present. So I begin with the differences.

\section{Features that differentiate strands}

Strands differ from each other in five ways: (a) the person's role, (b) the cast, (c) the setting, (d) norms and values, and (e) habits and routines.

Role Imagine the case of Sarah, an attorney and a single mother. She might think of two of her strands as ATTORNEY and MOTHER. In each of these she has a position (or status) role, one associated with her position in an organization (such as her law office) and the other associated with formally organized groups, such as her family. ${ }^{2}$

Cast When Sarah is in her ATTORNEY strand, she interacts with a cast of people who inhabit it or enter into it. Some of them have long-term roles in relation to her (colleagues, partners, or staff), or others have transitory ones (clients, other officers of the court, or government bureaucrats).

Setting Sarah's ATTORNEY strand has a primary setting, her office, and secondary settings, such as court or other places where her professional activity may take her, or even home, where she may need to do some of her work. A strand that can be enacted in more than one location is said to be flexible (Hall and Richter, 1988). Her MOTHER strand also has a primary setting, home, and many secondary settings, such as the supermarket, day-care center, a friend's home, or the home of Sarah's parents. Clearly Sarah's MOTHER strand is more flexible than her ATTORNEY strand. When she's in a public secondary setting she doesn't exit the MOTHER strand, although she may need to adjust her behavior to suit the setting (such as breastfeeding, or changing diapers, Giles, 2018).

Values and norms A person's understanding of the context or situation in which she finds herself modulates her thoughts, feelings, and actions (Mischel, 2004; Mischel and Shoda, 1995, 2010). And since a strand is a particular kind of situation - one that is familiar and predictable — it constrains behavior by triggering values and norms (Cialdini et al., 1990; Judge et al., 2014; Kallgren et al., 2000; Leung and Morris, 2015).

Values. To illustrate how values may vary from strand to strand, I draw upon Schwartz's view of the organization of values (Borg et al., 2015; Cieciuch et al., 2014; Schwartz et al., 2012). When Sarah is in her ATTORNEY strand, she needs to be self-directed, focused on achievement, and power. But when she is in her MOTHER strand, she is benevolent and tolerant, values that do not leap to mind when we think of attorneys. Of course, some values may be strong in both strands, such as a desire for security, both personal and social. ${ }^{3}$

Norms. Just as values vary from strand to strand, so do social norms that govern (or restrain) our behavior (Bargh and Williams, 2006, p. 1). Take clothing, for example: as ATTORNEY, Sarah is likely to adhere to a dress code that requires formal clothing (Farmer, 2010; Gurung et al., 2017; Slepian et al., 2015). ${ }^{4}$ But as MOTHER, Sarah will find few constraints on how she should dress at home (e.g., Wallace, 2015), and she may not care much. Language too is strand-dependent: as ATTORNEY she needs legal English (Tiersma, 2000), but as MOTHER she may use motherese (Blount and Kempton, 1976).

Habits and routines As Ersche et al. (2017) remark:

Our daily lives involve high levels of repetition of activities within similar contexts. We buy the same foods from the same grocery store, cook with the same spices, and typically sit at the same place at the dinner table. However, when questioned about these routine activities, most of us barely remember the details of our actions. Habits are automatically triggered behaviours in which we engage without conscious awareness or deliberate control. (p. 73)

In other words, habits are strand-specific activities with two central features: routineness, implying frequent repetition, and automaticity, implying minimal demand for cognitive resources (Ersche et al., 2017, §3.1). ${ }^{5}$ Although habits generally resist change (Nordfjærn et al., 2014), under some 
circumstances they may change to minimize effort (Zhu and Risko, 2016), and under other circumstances they may even become virtuoso performances (Bourdieu, 1977, pp. 8, 79; ${ }^{6}$ 1990, pp. 57, 107), such as the efficiency of a master chef, the effortless grace of an athlete, or a brilliant performance by a musician.

Each strand draws upon strand-specific habits, skills, scripts, and plans (Schank and Abelson, 1977). For example, in her ATTORNEY strand Sarah may write appellate briefs, mostly assemblages of boilerplate, and in her MOTHER strand she may follow well-honed routines to provide her child's daily needs (such as feeding and dressing), as well as the household's needs (such as planning the week's menu and shopping).

Enumerate strands? Some strands, such as SON or DAUGHTER are universal. Others are widespread, such as SPOUSE Or PARENT. This raises the question of whether we can, or should, enumerate strands. I do not think that this would be advisable, because doing so a priori would not be in keeping with adopting a first-person point of view. Nevertheless, it may be possible to categorize strands in a manner inspired by Andrews and Withey (1976), who in their work on social indicators of well-being, defined life domains as "places, things, activities, people, and roles." Drawing on several authors (Andrews and Withey, 1976; James and Asmus, 2001; Roberts and Clement, 2006), such categories could include: (a) family, (b) work, (c) shelter, (d) health, (e) community, (f) leisure, (g) politics.

\section{Features strands share}

Please see Figure 1 for an encapsulation of the following description.

Projects and episodes Strands contain events and activities. If Sarah remembers that an event took place, even if she can't recall when, she will remember that it began and ended at determinate times. These are temporally determinate events or activities. Most temporally determinate events occur within a strand.

Other events - which Kubovy (2015) called preoccupations - are not determinate in time, because they infiltrate current events or activities. They may involve the past (such as, guilt, regret, or pride), the future (such as, hope, fear, or worry), or the present (such as pain, hunger, or the need to void). When they are negative and persistent (and involve the past or the future) they are instances of rumination (Lyubomirsky et al., 2015). If they are positive or neutral, they constitute mind-wandering (Smallwood and Schooler, 2015).

Temporally determinate activities fall into three categories: (a) projects, (b) episodes, and (c) routine activities (discussed earlier, page 3). Projects and episodes consist of a sequence of events (Figure 2). Each has an initial event and a terminal event.

Projects Projects are sequences of activities designed to achieve a goal. For example, in her MOTHER strand Sarah will promote good hygiene practices (Matson, 2017), model emotional responses to good and bad behavior (Quinn, 2003, Quinn and Mathews, 2016, pp. 372-378), shape her child's use of language (Duranti et al., 2012), and political values (Quintelier, 2013).

People have at least four reasons to initiate a project. A project may be:

(a) Strand-obligatory. For example, the project of toilet training is built into the MOTHER strand. How Sarah goes about this is up to her (but it is likely to be influenced by her upbringing, Spinelli et al., 2015; and her educational attainment, Sieben, 2017).

(b) Self-initiated, such as buying a piano and hiring a piano teacher for her child.

(c) Assigned. For example, in her ATTORNEY strand, Sarah may be assigned the task of working on a merger of two companies.

(d) Obstacle-clearing. These are inevitable, because projects often run into trouble. For example, in the midst of the merger negotiations, Sarah may run up against a disagreement between the parties about intellectual property, and she will need ingenuity and diplomacy to resolve it.

Little and colleagues (Argyle and Little, 1972; Little, 1983, 2013; Little et al., 1992; Little, 1993, 1996, 1999a,b, 2000, 2014) have suggested that there is another important, perhaps essential, category of project: personal 


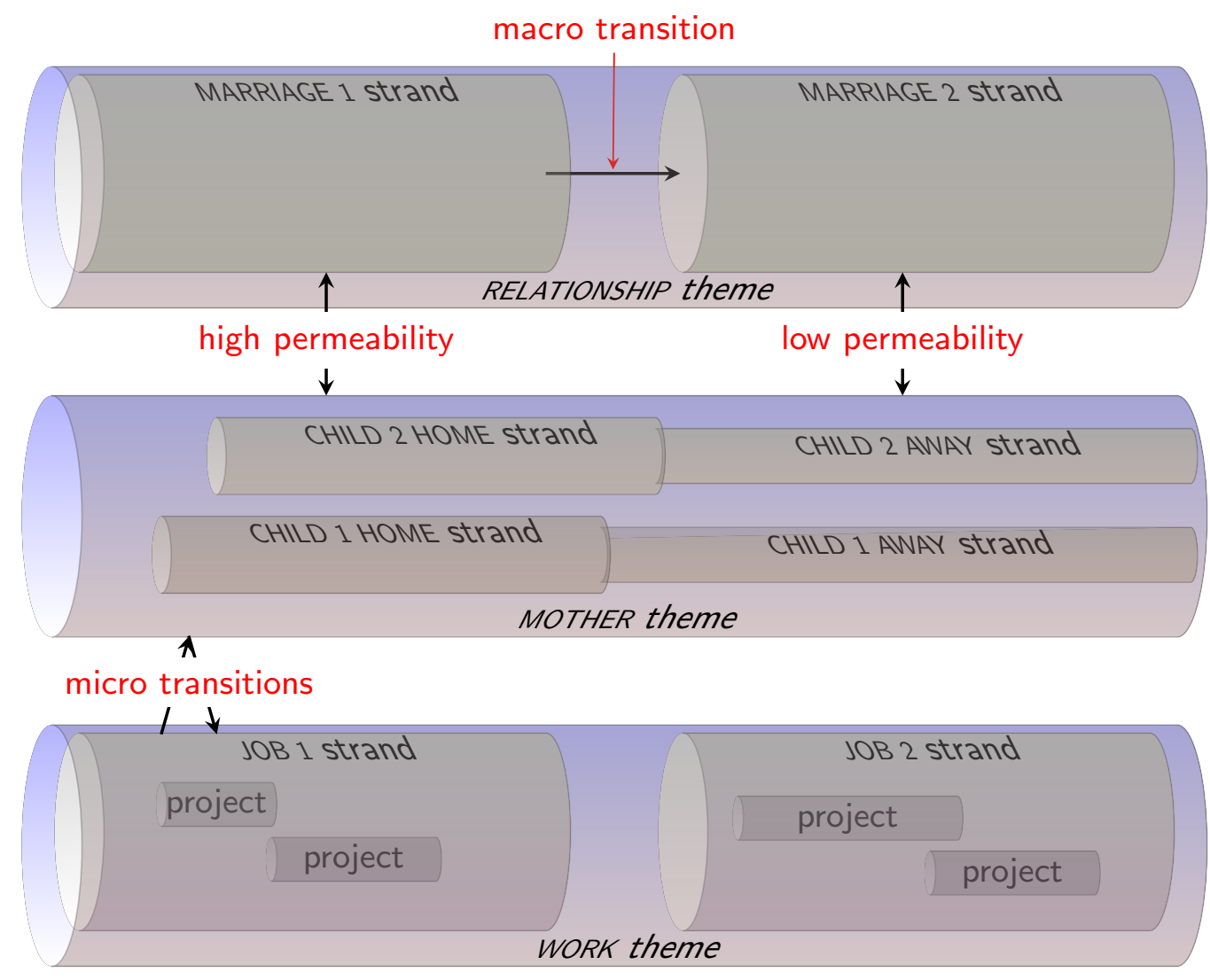

Figure 1. Strands, themes, and projects

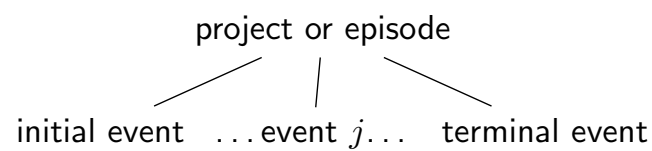

Figure 2. Projects and episodes consist of a sequence of events.

or intrapersonal projects such as "be more outgoing with my clients," "try not to get angry at the kids for being away all the time," and "be more open to others." The examples they offer suggest that such projects do not encompass all the domains of a person's life. Instead, they unfold within strands: being more outgoing with clients would be pursued in a WORK strand, not getting angry with the kids - in a PARENT strand, and being open - in a SOCIALIZING strand.

Episodes In addition to habits/routines and projects, lives contain episodes. As Bruner (1991) puts it, episodes are generally the result of an implicit canonical script [having] been breached, violated, or deviated from. (p. 11)
Some episodes may be confined to a strand, such as the events leading up to the firing of a partner in Sarah's law firm, but many are not. Some episodes Sarah experiences first-hand (having her car rear-ended while driving to an appointment), others she experiences second-hand (hearing of the confirmation of a Supreme Court Justice), and yet others she experiences virtually (through a work of literature, film, or visual art; Kubovy, 1999).

Episodes have two central features: (a) they often engender narratives, and (b) when these narratives are shared or remembered they are continuous.

Narratives According to Labov and Waletzky (1997), narrative is a 
...verbal technique for recapitulating experience - in particular, a technique of constructing narrative units that match the temporal sequence of that experience. (p. 4)

The temporal sequence of events that can be inferred from a narrative has been called (since Shklovsky, 1965, and other Russian formalists) the fabula of the narrative. Undoubtedly, a story may become more interesting if the narrator uses devices such as flashbacks, in which case the telling deviates from the chronological order of events (the Russian formalists called this the narrative's sujet). Although flashbacks have been used in literature since the Odyssey, they are rare in personal narratives (Labov, 1997).

The circumstances for the generation of a narrative are social. A typical prompt is a question (Labov, 2006), such as Zilber et al. (2008):

Okay, so tell me how you have reached this situation, that you are a single mother of a 10 -year-old boy. You may start wherever you wish.

Another common impetus for the generation of a narrative is the conclusion of a project. When a goal is achieved (and sometimes when it isn't) it is eminently reportable or tellable (Fludernik, 1996; Norrick, 2005) or noteworthy (Kubovy, 2015). Likewise, an episode gives us a reason to generate a narrative because, as we saw earlier (page 5), the essence of an episode is to contain a tellable event.

Continuity Earlier I argued that strands contain two kinds of narratable sequences of events: projects and episodes. This narratability endows strands with continuity.

Let us revisit the project undertaken by Sarah in her ATTORNEY strand (page 4): the merger of two companies. Suppose that, in the course of the negotiations, there is a disagreement about intellectual property, which takes a few days to clear. During this time, Sarah lives her life as usual, alternating between strands: MOTHER $\Rightarrow$ ATTORNEY every morning, and ATTORNEY $\Rightarrow$ MOTHER every evening (these are micro-transitions; Ashforth et al., 2000). Indeed she lives what Simmel (2002) called a metropolitan life, which requires that
... all of its activities and reciprocal relationships [be] organized and coordinated in the most punctual way into a ... framework of time … (p. 13)

In other words, it is governed by clock and calendar time (CC time) (Postill, 2002).

But there is reason to believe that strands are not governed by CC time (page 6). Organizing our activities by strand is incompatible with it. Indeed, memory is not organized by temporal continuity but by narrative coherence (Friedman, 2004; Hintzman, 2016). To quote Rubin and Greenberg (2003):

Narrative establishes a major form of organization in autobiographical memory, providing temporal and goal structure. Autobiographical memories are usually recorded as narrative; they are told to another person and to oneself. Inclusions and exclusions depend in part on the narrative structures used. If information is not central to the narrative structure, it is less likely to be remembered. (p. 61)

Wagenaar (1986) provides a vivid example. Over a period of five years he kept a diary of personal events. For the days on which the diary contained at least two events, he tested whether the presentation of one of them would elicit a recollection of the other. It did not: out of 314 pairs, he succeeded only 22 times. And when he did succeed, it was because the two events occurred in the same location, i.e., they probably took place in the same strand (p. 246).

This does not mean that we are necessarily good at remembering sequences of events that occurred within the same strand. Unless two events within a strand are spontaneously inserted into the same narrative, their order might be difficult to remember.

Returning to Sarah's negotiations: After she concludes them, she needs to report the successful outcome to her client. In generating her narrative, she has no reason to remember (let alone report) that between drafting two sections of the agreement, a micro-transition took place, because she went home. Neither her recollection of the project or the narrative she may construct is likely to mention such interruptions. This is true in general: when 
one recalls a project, $\mathrm{CC}$ time interruptions are suppressed. ${ }^{7}$ This is tantamount to saying that we tend to represent projects to ourselves, and to others, as continuous. Or perhaps it might me more prudent to say that when we recollect projects, we elide discontinuities unless doing so would reduce the informativeness of the account. ${ }^{8}$

There are, however, inevitable discontinuities in lives. Some scholars (Bohn and Habermas, 2015; Brown, 2016; Brown and Lee, 2010; Brown et al., 2016; Enz and Talarico, 2015; Shi, 2017; Pillemer, 2009; Uzer and Brown, 2015) have drawn a distinction between turning points in lives, which are changes in life direction, such as St. Augustine's conversion at Ostia (Saint Augustine of Hippo, 1997, IX, $\mathrm{x}, 23-25)$, and transitions, which are external changes in daily circumstances, such as Primo Levi's transport to Auschwitz in 1944 (Levi, 2015). Regardless of whether they are internally driven or externally caused, these have been called macro transitions (Ashforth et al., 2000).

Within a culture, some macro transitions are shared by many (such as leaving home, or taking a first job), and occur in a fairly predictable order and at a fairly predictable age. Shi (2017) has called these script-consistent transitions. ${ }^{9}$ It is important to keep in mind, however, that the scripts themselves have been changing over time (Burgin et al., 2017), so that many transitions that are script-consistent today, would not have been so a century ago. Other transitions are script divergent (such as a break-up or the death of a close friend), and are most often painful and involve loss; their timing is unpredictable.

Because projects and episodes lie at the core of strands, their continuity is true of strands as well. When one recalls the evolution of a strand, interruptions are not represented. Exceptions may occur, however, when a strand undergoes a macro transition, as would occur were Sarah to take an extended maternity leave (I return to this issue later).

Even if a life undergoes a severe macro discontinuity that destroys a strand (such as a divorce, or losing a job), a larger scale continuity is possible. When such a transition occurs, there is often the possibility (and the desire) to begin a new strand of the same general kind, i.e., belonging to the same theme. Themes manifest themselves in autobiographical memory (Barsalou, 1988; Belli, 1998; Conway, 1992, 1996; Conway and Pleydell-Pearce, 2000). Burt et al. (2003) had students record their experiences over their summer vacation. Subsequently, for each day in a student's diary, the experimenters transcribed at most one entry onto a card. Then the diarists were given their entries in a random order, and asked "to arrange them so as to describe themes in your life." By and large, these clusters shared content rather than temporal sequence (see also Burt et al., 2008; Kemp et al., 2009). (In laboratory studies, Tzeng and Cotton, 1980, have shown that the order of events is remembered far better when items are semantically related, suggesting that people would also remember the order of autobiographical events if they belonged to the same strand. ${ }^{10}$ )

\section{Relations among strands}

Boundaries Strands partition our lives into categories, which provide us cognitive economy (Daniel et al., 2015; Huys et al., 2015; Rosch, 1978), and social clarity (Ashforth et al., 2000; Kallens et al., 2018; Nippert-Eng, 1996; Zerubavel, 1991, 1996, 2016). This partition implies boundaries (Allen et al., 2014; Barrett, 2014; Daniel and Sonnentag, 2016; Fleming and Waguespack, 2007; NippertEng, 2008; Pachucki et al., 2007), which have been a core concern of the work-family literature. In this field, scholars have made two distinctions ${ }^{11}$ (Ashforth et al., 2000): (a) thick or impermeable strand boundaries (i.e., compartmentalizing ATTORNEY and MOTHER) vs. thin or permeable strand boundaries (i.e., blending ATTORNEY and MOTHER), and (b) two types of strand transitions, (i) micro, which are frequent (e.g., the commute from MOTHER to ATTORNEY to MOTHER again), and (ii) macro strand-transitions, which are infrequent and often involve permanent change (such as a promotion or a divorce).

Even when the boundary between strands is thick, intrusions between them are inevitable. For example, Sarah may need to take a day off from work if her child is ill.

The possible existence of impermeable boundaries raises the issue of extreme compartmentalization, which according to Showers and colleagues (Showers et al., 2015) — may be maladaptive for some individuals.

Asynchrony Boundaries do not only separate strands from each other, they create asynchronous clock domains, a concept I borrow from the field of semiconductor design. In 
electronic devices, different modules may have clocks with different frequency. This is surely the case with strands. Whereas Sarah's MOTHER strand is dense involving many events each day, as long as her mother does not require frequent assistance, and is still independent, her DAUGHTER strand may consist of one phone call a week. Even though the strands do not share a clock, one can say that many events in her MOTHER strand occur between events in her DAUGHTER strand.

Although in electrical engineering the problem of crossclock-domain data transfer is crucial, this is not the case with strands. There is rarely a good reason for events in one strand to be registered in another. Take the case of an intrusion of one strand into another, a fairly common occurrence. Imagine a time when Sarah's DAUGHTER strand intrudes into her ATTORNEY strand: while Sarah is at work, her mother calls to ask that she renew a prescription. Sarah makes a mental note of the request (generating a prospective memory; Rummel and McDaniel, 2019), and when she has a free moment, takes care of it. But she there is no reason for her to also make a mental note of what she was doing when she received the call. The event belongs to her DAUGHTER strand and has no place in her ATTORNEY strand.

There are exceptions to the asynchrony of strands. There are times when macro transitions occur at the same time in many strands (we first discussed such transitions on page 7 , where we gave the examples of leaving the parental home, or getting a first job). According to transition theory (Brown et al., 2012; Svob and Brown, 2012), subsequent events may be timed in relation to these transitions (Uzer and Brown, 2015), much as historians divide the calendar into BCE (before the common era) and CE (common era). Furthermore, if a sudden transition threatens the entirety of one's strand structure, a person might register a flashbulb memory (Hirst and Phelps, 2016; Hirst et al., 2015; Kraha et al., 2014).

Intensity, importance, and satisfaction Not all strands are equally intense, nor need we assume that their intensity is constant over time. For example, Sarah's MOTHER strand waxes and wanes over time, and eventually (under usual circumstances) diminishes. Just as one can assess the effort required by a job (Cooman et al., 2009) one could assess the intensity of a strand. Sarah's DAUGHTER strand would would likely become more intense as her mother grows dependent upon her. The degree to which it feels intense to Sarah depends on the previous quality of the relationship, the investment of time it entails, the frequency with which it intrudes on other strands, the conscientiousness it demands, and the persistence it requires.

Even if two strands are of equal intensity, they may be of different importance. Consider the case of Stephen Hawking, the prominent cosmologist who suffered from amyotrophic lateral sclerosis, which is frequently accompanied by pain (Moisset et al., 2015), and depression (Kübler et al., 2005), and requires 5 to 15 hours of care per day (Chiò et al., 2006). And yet, in his autobiography Hawking (2013) mentions his illness only six times, and talks mostly about the evolution of his theories, and to a lesser extent about his personal life.

\section{Single stream vs. multiple streams}

In Figure 1 I represented themes and the strands they contain as parallel tubes. One might question this representation, because it does not show that one can only inhabit one strand at a time. The very question arises from a deeply ingrained view of lives, which I will call the single-stream view. After I portray this view, I present an alternative, the multiple-stream view.

\section{The single stream view}

The idea of life as a single stream has been the default in many fields of thought. For example, Descartes (2017) emphasized singleness:

When I consider the mind - i.e. consider myself purely as a thinking thing - I can't detect any parts within myself; I understand myself to be something single and complete. (p. 32)

Nearly two and a half centuries later, William James (1884) added continuity to singleness:

We can ... represent ... the subjective stream by a continuous line, and if ... we wish to 
isolate any portion of it for examination, we can symbolise that isolation by making crossstrokes. But, ...the cross-strokes do not preexist. They are "artefacta"; and the natural function of every segment of the line is to lead continuously into the next segment and carry consciousness along unbroken. (p. 9)

This idea has been so widely embraced that it has become axiomatic. I will call it the William James axiom (WJA).

When psychology came of age, it didn't question the WJA. Late in the 20th century it was represented by Barker's (1965; 1963) stream of behavior. His colleague, Dickman (1963), wondered how we parse the continuous stream of consciousness into perceived temporal units. A decade later, Newtson (e.g., Newtson, 1976; Newtson et al., 1987) addressed the question systematically. After his research program went dormant, it was revived by Zacks and Tversky (2001), and it became a burgeoning field of study (summarized by Radvansky and Zacks, 2017).

The WJA was also adopted by theorists of consciousness such as Baars (2011, p. 68), who writes: "There is no such thing as true psychological simultaneity of two distinct events ..." It is also appealing because it comports with our linguistic intuitions. We have no trouble understanding Dante when he opens the Inferno (1996) with

Midway on our life's journey, I found myself In dark woods, the right road lost. ...

because — as Lakoff and Turner (1989) point out — it draws upon a universal conceptual metaphor, LIFE IS A JOURNEY, i.e., a single stream.

\section{The multiple stream view}

Despite this wide agreement, there are good reasons to explore an alternative view. Consider Sarah's ATTORNEY and MOTHER strands. There is nothing inherently wrong in describing a day in her life as a series of interleaved ATTORNEY and of MOTHER experiences, as depicted in Figure 3a. But if we took this description at face value, it would imply that while she is in her ATTORNEY strand, her MOTHER strand is interrupted, which is surely not how she experiences her life. Although she may not pay attention

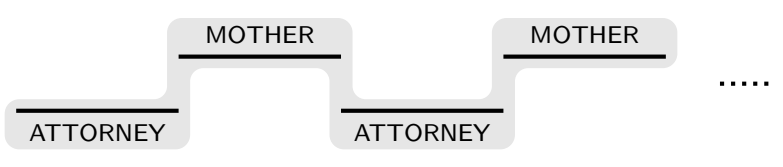

(a) A single stream of interleaved activities.

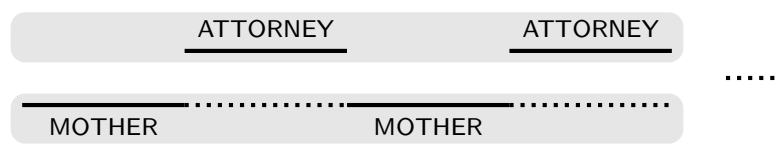

(b) Multiple streams: when Sarah is in her ATTORNEY strand, ATTORNEY is figure and MOTHER is ground.

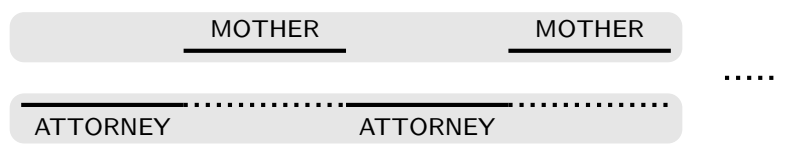

(c) Multiple streams: when Sarah is in her MOTHER strand, MOTHER is figure and ATTORNEY is ground.

Figure 3. Graphic representations of two views of the structure of lives. Figure 3a: representing a life as a single stream alternating between strands. Figures $3 \mathrm{~b}$ and $3 \mathrm{c}$ : representing a life as multiple streams with concurrent strands that alternate between being figure and ground.

to her MOTHER strand while at work, she surely doesn't momentarily experience herself as being childless.

A more faithful representation of her experience might be as in Figures $3 \mathrm{~b}$ and 3c. Her MOTHER strand is continuous and uninterrupted, but when she's at work, her MOTHER strand is in the background. In other words, each time she arrives at her office, there is an initial moment in her ATTORNEY strand, but there is no corresponding terminal moment in her MOTHER strand. Likewise, when she leaves her office, there is a terminal moment in her ATTORNEY strand, but no concurrent revival of her MOTHER strand.

Of course, the idea comes from perception. In Rubin's famous vase/faces demonstration (Rubin, 1958, 1921, 1915; Wagemans et al., 2012), when we see the vase in the foreground, the edges of the vase are vase-edges, but there are no corresponding face-edges. We see the black area as an uninterrupted backdrop extending behind the vase; the faces are not present. ${ }^{12}$

There is an even better analogy between multiple streams and perception — it's called auditory stream segregation. ${ }^{13}$ The question is, How do we perceive tones played in a

$$
\ldots-A B A-A B A-A B A-A B A-A B A-\ldots
$$


pattern? When the tempo is moderate and the pitches of $A$ and $B$ are not too far apart, it sounds like a single stream of notes that form a galloping rhythm. But when they are alternated at a faster tempo and their pitches are further apart, we hear two streams. It is remarkable that when we hear two streams, we also have trouble hearing the temporal relationship between them (van Noorden, 1975, §6); they are perceptually asynchronous.

An analogous cognitive phenomenon is threaded cognition (Salvucci and Taatgen, 2008). Suppose a cook is preparing a meal of baked fish, pasta, and a cake. The recipes for each dish are independent - a skillful cook could readily replace any of these dishes with another but the resources (the cook, the single oven) are not. Cooks, even though they can only do one thing at a time, must hold multiple concurrent tasks in mind, and execute the next step in each recipe, taking into account available resources. As a consequence they must keep track of those tasks that are unfinished.

Memory reflects the pervasiveness of such tasks. Indeed, we often remember incomplete tasks better than completed ones, a phenomenon known as the Zeigarnik effect (1927; 2016, replicated by Seifert and Patalano, 1991).

These two phenomena, auditory stream segregation and threaded cognition, show that humans have the wherewithal to experience multiple concurrent streams of behavior. This idea has begun to gain traction. In light of Kubovy (2015), Richmond and Zacks (2017) believe that accounts of how behavior is parsed into temporal units (mentioned earlier, page 9) should include a multiple streams component.

\section{Nonadditivity}

Is the value of a life the sum of its parts? The question can be interpreted in two ways: is it the sum of the value of its moments within a strand, and is it the sum of the value of its strands at a particular moment.

\section{Over time}

Kahneman and Riis (2005) distinguish between an experiencing self and a remembering self.

An individual's life could be described ... as a string of moments. [Assuming] that each of these moments of psychological present may last up to 3 seconds $^{14} \ldots$ people experience ... upwards of 500 million moments in a 70year life. ... What happens to these moments? ...they simply disappear. ... When we are asked 'how good was the vacation,' it is not an experiencing self that answers, but a remembering and evaluating self, the self that keeps score and maintains records. Unlike the experiencing self, the remembering self is relatively stable and permanent. It is a basic fact of the human condition that memories are what we get to keep from our experience, and the only perspective that we can adopt as we think about our lives is therefore that of the remembering self. (pp. 285-286)

What I have been describing in the article appears to be a fleshing-out of Kahneman and Riis's remembering self.

But Kahneman and Riis take this idea a step further: they claim that when we evaluate an experience, we should not rely exclusively on the remembering self. Instead, we should consider the value of an experience (and by extension, of a life) as the sum of the values of its moments. To persuade us, they offer an example:

consider a music lover who listens raptly to a long symphony on a disk that is scratched near the end, producing a shocking sound. Such incidents are often described by the statement that the bad ending 'ruined the whole experience.' But, in fact, the experience was not ruined, only the memory of it. The experience of the symphony was almost entirely good, and the bad end did not undo the pleasure of the preceding half hour. The confusion of experience with memory that makes us believe a past experience can be ruined is a compelling cognitive illusion. The remembering self is sometimes simply wrong. (p. 286, emphasis mine)

They undoubtedly have a point when they claim that the bad ending would not have ruined every minute of the experience. But by the same token, it makes little sense to 
claim that the shocking sound would have only ruined a 3second "moment." To enjoy music we must retain what we just heard and experience the "sweet anticipation" (Huron, 2006) of how the music is likely to unfold. Husserl (1991, p. 37) called this protention, illustrated by Blaiklock's (2017) description of a deceptive cadence in

... Bach's Passacaglia and Fugue in $\mathrm{C}$ miinor, BWV 582. ... a series of dominant chords ... lead[s] us to protend a coming dominant cadence resolving to the tonic, but instead there is an unexpected D flat major chord. We hear in protention the melody resolving one way ... what we get instead is a different chord and the continuation of the piece. (pp. 476-477)

Nor are such devices are restricted to "classical" music (Capitain, 2018). The duration of protensions varies from one musical style to the other, but during the time of Haydn, Mozart, and Beethoven (Rosen, 1972), for example, music was based on four-measure phrases, no less that 10 seconds long (see Bigand and Poulin-Charronnat, 2006, for a review of the relevant empirical evidence), which were often combined into "sentences," of eight measures (Caplin, 2000 , p. 59). This is also true of popular music (Robins, 2017). In other words, even the experiencing self does not just live in a 3 -second present.

The momentariness of the experiencing self becomes even less persuasive if we consider suspense. Carroll (1990) asks us to reflect upon a "shopworn example":

...the heroine is tied to the railroad track; the locomotive is steaming at her. Will she be crushed or saved? (p. 137)

Suspense requires two ingredients: (a) a future-oriented emotion such as hope (e.g., of getting a job) or fear (e.g., of being found guilty), coupled with (b) an estimate of likelihood. In the case of the heroine on the track, we experience suspense because we can't see how she could be saved. So, we fear that she will die, a high-probability event, and we hope that she will be saved, a low probability event (Table 1). But hope and fear are not about the present; they involve complex constructive processes. As Kahneman and Miller (1986) convincingly showed, many emotions
Table 1. The structure of suspense (according to Carroll, 1990, p. 138, updated by Lehne and Koelsch, 2015).

\begin{tabular}{rcc}
\hline \multirow{2}{*}{ emotion } & \multicolumn{2}{c}{ probability } \\
\cline { 2 - 3 } & high & low \\
\hline hope & & suspense \\
fear & suspense & \\
\hline
\end{tabular}

(such as surprise, frustration, regret, hope or fear) require a tacit comparison of one reality (either past or future) to a counterfactual one. So if Kahneman and Riis's experiencing self can experience such emotions, it can't be very different from the remembering self.

If the sum of the value of moments represents the value of an experience then we must also believe that once we have had an experience, it cannot be changed. Indeed, historic events cannot be changed once they have occurred; no one will deny that Krakatoa erupted in 1883. But experiences are not historic events. Experiences are never uninterpreted, never raw, never free from constructive processes. As so it is inevitable that the value of some experiences may be reassessed in the light of subsequent information. Isabel Allende's (2017) story, In the Midst of Winter, illustrates this point. Lena is informed that her husband - whom she had loved "from the age of seventeen with unswerving devotion" — has died. Soon thereafter she learns that

... her husband was a bigamist. Lena's mourning was transformed into a storm of resentment and retrospective jealousy. She spent months scouring the past for lies and omissions, piecing things together to explain every suspect act, every false word, every broken promise, doubting even the way they had made love. (pp. 53-54)

For all these reasons, I believe that experiences acquire value not through the accretion of moments, but as an emergent property of the organization of such moments, much like a melody is an emergent property of the organization of its notes.

\section{Across strands}

There are two arguments against the additivity of the values of a person's strands in determining her evaluation of her 
life at a given moment. To make these points, I deviate from the approach taken up to now in two ways. First, I do not rely on a description of lives in general. Instead I consider people who are uncommon and admired. Second, I depart from the first-person perspective. Instead, I describe a thirdperson understanding - not necessarily accurate - of the first-person perspective of these individuals.

The first argument draws upon the example of severely challenged people who acquire skills out of the reach of most of us and yet appear to live (at least from a thirdperson point of view) a rich and fulfilling life (Table 2). This suggests (a) that the strand in which the great achievement was attained was insulated from the suffering caused by illness or the challenge posed by the physical limitation, and (b) that the person could relegate to the background the strand in which the suffering occurred, while maintaining as figure the strand in which great things were being done.

The second argument against additivity comes from cases of extreme self-sacrifice.

So when is an act of self-sacrifice seen to be worthy of sanctification? Only when the act appears not to be in the martyr's best interest, as understood by those who venerate it.

There is a symmetry between these arguments. We give admiration and even reverence to two categories of individuals. (a) People who can foreground a strand in which they they have notable achievements, while appearing to disregard strands in which they experience great suffering. (b) People who appear to disregard strands in which they have love and satisfying work, while they foreground a strand devoted to a higher cause in which they will experience great suffering. ${ }^{15}$

\section{Data: A proposal}

What would it take to obtain a first-person view of an individual's strands and an understanding of the relations among them? To this end, the author and colleagues have proposed a smartphone app called LifeMaps (Mondol et al., 2016). ${ }^{16}$ LifeMaps, which exists in prototype form, is designed to be an on-line diary system that collects structured data from a person using both automatic sensing and manual inputs. It would also accept special-purpose extensions designed for clinical applications and behavioral studies.

Figure 4 shows a simplified version of the user interface. The leftmost column in the right-hand field of the interface is a list of times at which each activity began. The next column lists the type of activity (whether it is routine or part of a project) selected by a drop-down menu. If the user indicates that the activity is part of a project, then a screen opens to allow her to select the initial moment of the activity, thus linking all the activities of a given project. In the next column is an indication of the location of the activity (presumably identified by GPS and information from the person's linked calendar app). In the fourth column, the user is invited to briefly describe the activity. The fifth (and final) column is crucial. It gives the user the opportunity to designate which of the day's activities are noteworthy. For each activity marked as noteworthy, the user is given an opportunity to write about the activity, however much she wishes, explaining why it's noteworthy.

In the central area of the user interface each activity is numbered and placed in an icon with a shape that corresponds to the type of activity indicated in the second column. Each of these icons can be dragged into the black field on the left, into one of many boxes that can be added and given the a name to represent a cluster of activities. These boxes persist from day to day, and are empty at the beginning of each day. These are candidate strands.

LifeMaps combines features of the experience-sampling method (ESM, Palmier-Claus et al., 2019) and the Day Reconstruction Method (DRM, Kahneman et al., 2004), but it allows us to go beyond what Kubovy (2015) has described as a "flat" succession of episodes. For example, ESM can only sample discrete moments of a life with respect to a small number of categories, thus giving neither a comprehensive view of the cross-sectional structure of a life nor a sense of its longitudinal structure. Similarly, the DRM asks people to treat their activities during a day as if they were a chronological sequence of scenes in a film. This too can only get at the surface structure of lives, because it does not offer tools for the recognition of the thematic link between (say) work before lunch and work after lunch.

The implementation of a successful LifeMaps-based research program because it would have to satisfy four 
Table 2. People who achieved greatness while severely handicapped

\begin{tabular}{|c|c|c|}
\hline name & disease or handicap & achievement \\
\hline Jean-Dominique Bauby & locked-in syndrome & author (The Diving Bell and the Butterfly) \\
\hline Ludwig van Beethoven & deaf & composed his Ninth Symphony while completely deaf \\
\hline Christy Brown & cerebral palsy & painter and poet, wrote My Left Foot, his autobiography \\
\hline Sudha Chandran & leg amputee & acclaimed Indian dancer \\
\hline Frida Kahlo & polio, spina bifida, chronic pain & painter \\
\hline Helen Keller & blind and deaf & author (The Story of My Life) and political activist \\
\hline $\begin{array}{l}\text { Marlee Matlin } \\
\text { John Milton }\end{array}$ & $\begin{array}{l}\text { deaf } \\
\text { blind }\end{array}$ & $\begin{array}{l}\text { Academy Award (Best Actress) for Children of a Lesser God } \\
\text { wrote Paradise Lost while blind }\end{array}$ \\
\hline Claude Monet & blind & painted Nymphéas while blind \\
\hline Shekhar Naik & blind & great Indian cricketer \\
\hline John Nash & schizophrenia & major mathematician, Nobel in economics for game theory \\
\hline Franklin D. Roosevelt & polio & president of the US \\
\hline Marla Runyan & blind & three times US champion in the women's 5000 meters \\
\hline
\end{tabular}

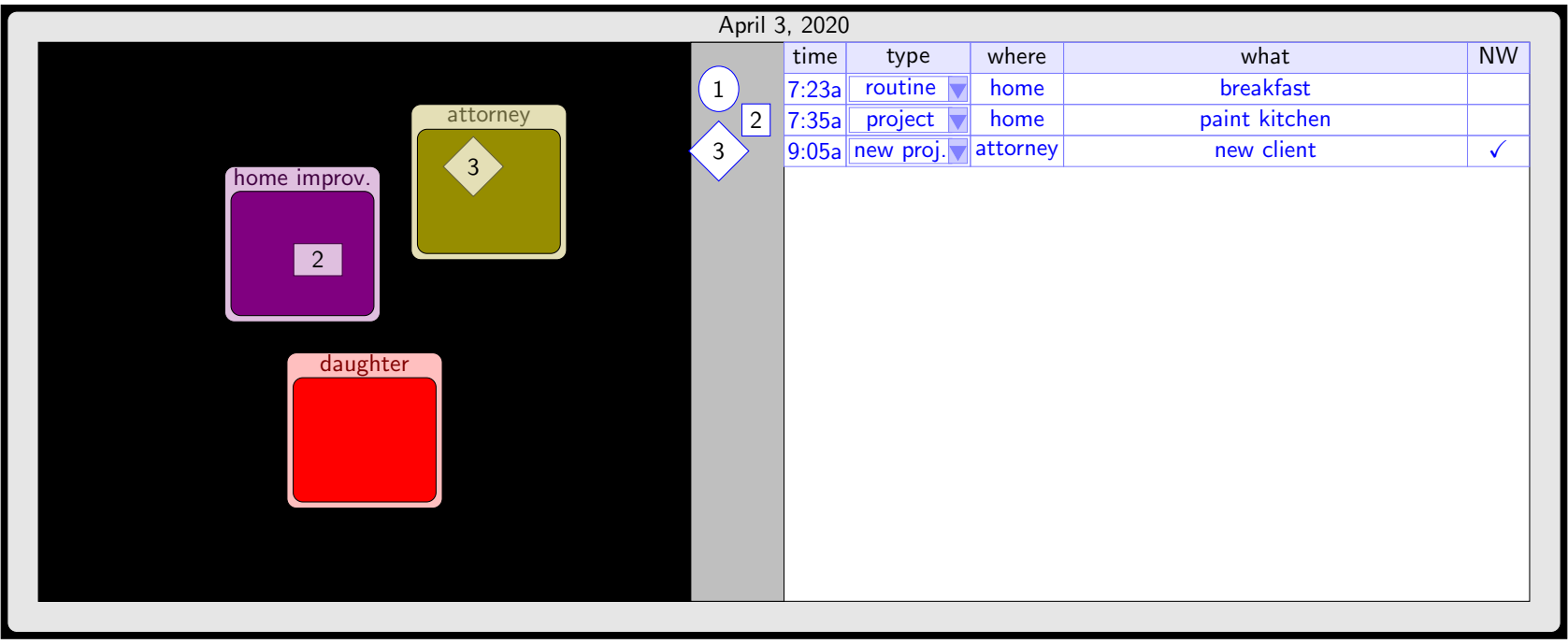

Figure 4. A mock-up of a screen of the LifeMaps smartphone app

challenging, but currently achievable, requirements. (a) It would not burden the user. To achieve this, LifeMaps should automatically collect data on the user's life (such as activities, mobility, and location) using sensors, and learn to infer the current activity with sufficient accuracy to minimize the number of corrective interventions required of the user. (b) It would guarantee the user's privacy. (c) It would have a large user base. To allow nomothetic results to be extracted from such idiographic data, it would have to be used by a sufficiently large and representative sample of a population. (d) It would host research projects. The developers of LifeMaps would offer a toolkit for the creation of special-purpose modules that would allow research groups to leverage the default data collected by the application. The modules could be just about any tool used in empirical cognitive or social psychological research, such as periodic ESM queries, questionnaires, implicit-bias studies, to name a few.

What kinds of data might one collect using LifeMaps? The easiest data to collect would be a cross-sectional study of the number of strands defined by users of different ages (keeping in mind the limitations of interpreting crosssectional data). These data would allow us to estimate the growth and decline of the number of strands over the lifespan.

Somewhat more involved would be an attempt to estimate the number of concurrent projects a user is juggling - especially those denoted noteworthy. This might allow us to assess the complexity and attentional demands of each strand. At the same time, by adding 
questionnaire extensions to the app, a we could find out how well the user likes each project, the strand as a whole, and her life satisfaction. And so we might hope to address empirically the question raised on page 11: is a person's evaluation of her life at a given moment, an additive function of her evaluation of her strands.

Finally, let us see how LifeMaps would be synergistic with current research. As an example, consider a study by Beck and Jackson (2019). They used a two-period ESM (where the assessments were either one or two years apart) to explore the stability personality assessed idiographically in a sample of students. Their models suggested that "some people were completely stable across two years whereas others were very unlike their former selves" ( $p$. 1 in the Online First version). Even though the results are interesting, Beck and Jackson recognize that their study was limited by the ESM method, which constrained it to assessing only nine behaviors from the Big Five Inventory. They recommended that future research assess a broader range of behaviors, using a larger number of time points, taken over a longer period, with a sample of adults rather than students.

If this study were done within the framework of LifeMaps, one could readily design an extension to achieve these goals. It would allow the study to sample a broader range of idiographic data, and to take many more assessments, and to sample a broader population. In addition, one could trigger ESM probes when the user enters one of the default locations for important strands (e.g., home for the MOTHER strand, and office for the ATTORNEY strand). Questions such as, "During the last hour, how happy were you?" or “... how 'outgoing, sociable' were you?", would be asked within different strands. This would allow researchers to determine the extent to which a person's personality differs in structure and stability from strand to strand.

\section{Conclusion}

In the introduction I gave reasons for developing a descriptive psychology. Of course, this is only an initial effort. But now that it is done, we should better understand its nature. It is best understood as an effort to put into words a shared understanding (a term of art in knowledge engineering, see Uschold and Gruninger, 1996) - much of which is tacit - of the structure of lives. Absent such an articulation, psychologists risk communicating poorly, and repeatedly inventing partial, parochial, and incommensurable conceptual frameworks.

But is it science? The standards by which the claims made here should be tested are not all that different from those used in linguistics (Schütze, 2016). Linguists use grammaticality judgments. Readers must judge what in this account fails to capture the shared understanding in question, and how they might improve upon it. If it does not describe their lives, it is wrong.

In his seminal article, "What Is It Like to Be a Bat?", Nagel (1974) writes:

At present we are completely unequipped to think about the subjective character of experience without relying on the imagination - without taking up the point of view of the experiential subject. This should be regarded as a challenge to form new concepts and devise a new method - an objective phenomenology not dependent on empathy or the imagination. Though presumably it would not capture everything, its goal would be to describe, at least in part, the subjective character of experiences in a form comprehensible to beings incapable of having those experiences. (p. 449)

The Structure of Lives is such an attempt.

\section{Acknowledgements}

I thank the many careful readers who have contributed to earlier versions of this article: J. T. Cargile, J. E. Cutting, W. R. Epstein, S. Gepshtein, L. Hallowell, J. A. S. Kelso, P. R. Killeen, A. Marasoiu, J. Shatin, M. Sheets-Johnstone, M. Sternberg, B. A. Teachman, T. D. Wilson, and J. M. Zacks.

\section{Notes}

1. A concern echoed in the field of organizational behavior by Kim et al. (2018). 
2. Koenig and Eagly (2014, Table 1) provide examples. In the vast literature on role theory (Biddle, 1986; Callero, 2008; Hindin, 2011; Oeser and Harary, 1962, 1964; Turner, 2001, pp. 233-234) sociologists distinguish position roles from (a) stable basic roles (gender, age, sexual orientation, or social class), and (b) temporary functional group roles (such as choosing to be a leader, a follower, or a devil's advocate).

3. I will not address personality, temperament, or motivation, except to note that personality and temperament probably determine the formation of strands (whether or not to have children, which profession to choose), and to point out (with Parks and Guay, 2009) that personality and values jointly determine motivations (as manifested in goal content, goal striving, and goal accomplishment).

4. Some of these ideas also appear in European sociology and philosophy (e.g., Bourdieu's, 1990, p. 53, concept of habitus).

5. With respect to the centrality of routines, strands resemble formal organizations. As Nelson and Winter (1985) show, the function of routines in organizations is analogous to the function of genes in evolutionary biology: they constrain the possible behaviour of actors, and are heritable over time, transcending individuals.

6. Bourdieu (1977, p. 8): "Only a virtuoso with a perfect command of his 'art of living' can play on all the resources inherent in the ambiguities and uncertainties of behavior and situation in order to produce the actions appropriate in each case, to do that of which people will say "There was nothing else to be done,' and do it the right way." See examples in People are Awesome (2015).

7. There may, of course, be exceptions. Sarah might choose to mention an interruption if it is germane to the narrative (e.g., a delay caused by the delivery of documents to the wrong address).

8. In keeping with Grice's (1975) conversational maxim of quantity.

9. Doherty and Cwick (2016) use the terms normative sequence or on time events.

10. I reached the same conclusions when I reanalyzed Kemp et al.'s raw data, kindly supplied by Dr. Simon Kemp on April $18,2018$.

11. Not to be confused with a homonymous concepts used in discussions of personality and dreams (Hartmann et al., 1991).
12. Many thinkers - some not well-enough known - have thought that the notions of figure and ground can fruitfully be applied to everyday experience: Bouman (1968, Chap. 4); Koffka (1922, p. 566); Bruckmüller et al. (2017); Lewin (1997); Sherif (1936, Chap. 3); Snygg (1941, pp. 414-415); Snygg (1949, pp. 27-28); Snygg and Combs (1949, pp. 23, 27, 37); Zerubavel (2015). The term foregrounding is sometimes used by psychologists who emphasize the importance of narrative in human lives (Polkinghorne, 1988; Schafer, 1992).

13. Stream segregation occurs in birdsong (Taylor, 2017, pp. 151-152), discovered by the musicians of sub-Saharan Africa (studied by Simha Arom, 1985, 1991, in the Central African Republic), and by composers in 17th century Europe (such as Bach, see Davis, 2006). It was rediscovered by psychologists (Miller and Heise, 1950; Heise and Miller, 1951), and described in detail by Bregman and Campbell (1971), and van Noorden $(1971 b, a)$ in the same year, an example of what Merton (1961), called multiples.

14. As estimated by Pöppel (2004).

15. In both examples, the admiration contains a hint of the supernatural that resists what Max Weber (1946, p. 139) called "the process of disenchantment."

16. The user interface was designed with Y. Spitsyn in 2010, and a working prototype was developed with J. A. Stankovic and A. S. Mondol in 2015. Several interdisciplinary teams at the University of Virginia and elsewhere worked with me on repeated attempts to secure funding for this project.

\section{References}

Allen TD, Cho E and Meier LL (2014) Work-family boundary dynamics. Annual Review of Organizational Psychology and Organizational Behavior 1(1): 99-121. DOI:10.1146/annurev-orgpsych-031413-091330.

Allende I (2017) In the midst of winter. Kindle edition. New York, NY, US: Atria Books. Translated from the Spanish by Nick Caistor and Amanda Hopkinson.

Andrews FM and Withey SB (1976) Social indicators of well-being: Americans' perceptions of life quality. New York, NY US: Springer.

Argyle M and Little BR (1972) Do personality traits apply to social behaviour? Journal for the Theory of Social 
Behaviour 2(1): 1-33. DOI:10.1111/j.1468-5914.1972. tb00302.x.

Arom S (1985) Polyphonies et polyrhythmies instrumentales d'Afrique Centrale. Paris, FR: SELAF.

Arom S (1991) African polyphony \& polyrhythm: Musical structure and methodology. Cambridge, UK: Cambridge University Press. Translation of Arom, 1985.

Ashforth BE (2001) Role transitions in organizational life: An identity-based perspective. Mahwah, NJ, US: Lawrence Erlbaum.

Ashforth BE, Kreiner GE and Fugate M (2000) All in a day's work: Boundaries and micro role transitions. Academy of Management Review 25(3): 472-491. DOI: 10.5465/amr.2000.3363315.

Baars BJ (2011) A cognitive theory of consciousness. Kindle edition published by the author edition. Cambridge, UK: Cambridge University Press.

Bargh JA and Williams EL (2006) The automaticity of social life. Current Directions in Psychological Science 15(1): 1-4. DOI:10.1111/j.0963-7214.2006.00395.x.

Barker RG (1963) The stream of behavior: Explorations of its structure \& content. New York, NY, US: AppletonCentury-Crofts.

Barker RG (1965) Explorations in ecological psychology. American Psychologist 20(1): 1-14. DOI:10.1037/ h0021697.

Barrett AK (2014) Breaking boundaries: Temporality and work-life practices in hospital organizations. Western Journal of Communication 78(4): 441-461. DOI:10. 1080/10570314.2014.926390.

Barsalou LW (1988) The content and organization of autobiographical memories. In: Neisser U and Winograd E (eds.) Remembering reconsidered: Ecological and traditional approaches to the study of memory, chapter 8. Cambridge, UK: Cambridge University Press, pp. 193243.
Bartlett FC (1932) Remembering: A study in experimental and social psychology. London, UK: Cambridge University Press.

Beck ED and Jackson JJ (2019) Consistency and change in idiographic personality: A longitudinal ESM network study. Journal of Personality and Social Psychology DOI:10.1037/pspp0000249. Online First Publication.

Belli RF (1998) The structure of autobiographical memory and the event history calendar: Potential improvements in the quality of retrospective reports in surveys. Memory 6(4): 383-406. DOI:10.1080/741942610.

Bernal JD (1939) The Social Function of Science. London, UK: Routledge.

Biddle BJ (1986) Recent development in role theory. Annual Review of Sociology 12: 67-92. DOI:10.1146/ annurev.so.12.080186.000435.

Bigand E and Poulin-Charronnat B (2006) Are we "experienced listeners"? A review of the musical capacities that do not depend on formal musical training. Cognition 100(1): 100-130. DOI:10.1016/j.cognition. 2005.11.007.

Blaiklock J (2017) Husserl, protention, and the phenomenology of the unexpected. International Journal of Philosophical Studies 25(4): 467-483. DOI:10.1080/ 09672559.2017.1342270.

Blount BG and Kempton W (1976) Child language socialization: Parental speech and international strategies. Sign Language Studies (12): 251-277. DOI:10.1353/sls.1976. 0016.

Bohn A and Habermas T (2015) Living in history and living by the cultural life script: How older Germans date their autobiographical memories. Memory 24(4): 482-495. DOI:10.1080/09658211.2015.1019890.

Borg I, Bardi A and Schwartz SH (2015) Does the value circle exist within persons or only across persons? Journal of Personality 85(2): 151-162. DOI:10.1111/ jopy.12228. 
Bouman JC (1968) The figure-ground phenomenon in experimental and phenomenological psychology. Stockholm, SE: Bouman.

Bourdieu P (1977) Outline of a theory of practice. Cambridge, MA, US: Cambridge University Press.

Bourdieu P (1990) The logic of practice. Cambridge, UK: Polity Press.

Bregman AS and Campbell J (1971) Primary auditory stream segregation and perception of order in rapid sequences of tones. Journal of Experimental Psychology 89(2): 244-249. DOI:10.1037/h0031163.

Brown NR (2016) Transition theory: A minimalist perspective on the organization of autobiographical memory. Journal of Applied Research in Memory and Cognition 5(2): 128-134. DOI:10.1016/j.jarmac.2016. 03.005 .

Brown NR, Hansen, B TG, Lee PJ, Vanderveen SA and Conrad FG (2012) Historically-defined autobiographical periods: Their origins and implications. Cambridge, UK: Cambridge University Press.

Brown NR and Lee PJ (2010) Public events and the organization of autobiographical memory: An overview of the living-in-history project. Behavioral Sciences of Terrorism and Political Aggression 2(2): 133-149. DOI: 10.1080/19434471003597431.

Brown NR, Schweickart O and Svob C (2016) The effect of collective transitions on the organization and contents of autobiographical memory: A transition theory perspective. The American Journal of Psychology 129(3): 259. DOI:10.5406/amerjpsyc.129.3.0259.

Bruckmüller S, Hegarty P, Teigen KH, Böhm G and Luminet O (2017) When do past events require explanation? Insights from social psychology. Memory Studies 10(3): 261-273. DOI:10.1177/1750698017701607.

Bruner J (1991) The narrative construction of reality. Critical Inquiry 18(1): 1-21.

Burgin R, Schumacher R and Ritschard G (2017) Changes in the order of family life events in 20th-century Europe:
A cross-regional perspective. Historical Life Course Studies 4: 41-58.

Burt CDB, Kemp S and Conway MA (2003) Themes, events, and episodes in autobiographical memory. Memory \& Cognition 31(2): 317-325. DOI:10.3758/ BF03194390.

Burt CDB, Kemp S and Conway MA (2008) Ordering the components of autobiographical events. Acta Psychologica 127(1): 36-45. DOI:10.1016/j.actpsy. 2006.12.007.

Calkins MW (1900) Psychology as science of selves. The Philosophical Review 9(5): 490-501.

Calkins MW (1915) The self in scientific psychology. American Journal of Psychology 26(4): 495-524.

Callero PL (2008) Role theory. In: Darity J William A (ed.) International Encyclopedia of the Social Sciences, volume 7, 2nd ed. edition. Detroit, MI, US: Macmillan Reference USA, pp. 275-276.

Capitain W (2018) Not a second time? John Lennon's aeolian cadence reconsidered. Rock Music Studies 5(2): 142-160. DOI:10.1080/19401159.2018.1484613.

Caplin WE (2000) Classical form: A theory of formal functions for the instrumental music of Haydn, Mozart, and Beethoven. Oxford University Press. ISBN 019514399X.

Carroll N (1990) The philosophy of horror: Or, paradoxes of the heart. Routledge. ISBN 9780415902168.

Chiò A, Gauthier A, Vignola A, Calvo A, Ghiglione P, Cavallo E, Terreni AA and Mutani R (2006) Caregiver time use in ALS. Neurology 67(5): 902-904. DOI: 10.1212/01.wnl.0000233840.41688.df.

Cialdini RB, Reno RR and Kallgren CA (1990) A focus theory of normative conduct: Recycling the concept of norms to reduce littering in public places. Journal of Personality and Social Psychology 58(6): 1015-1026. DOI:10.1037/0022-3514.58.6.1015. 
Cieciuch J, Davidov E, Vecchione M and Schwartz SH (2014) A hierarchical structure of basic human values in a third-order confirmatory factor analysis. Swiss Journal of Psychology 73(3): 177-182. DOI:10.1024/1421-0185/ a000134.

Conway MA (1992) A structural model of autobiographical memory. In: Conway MA, Rubin DC, Spinnler H and Wagenaar WA (eds.) Theoretical perspectives on autobiographical memory, chapter 10. Dordrecht, NL: Springer Netherlands, pp. 167-193. DOI:10.1007/ 978-94-015-7967-4_10.

Conway MA (1996) Autobiographical knowledge and autobiographical memories. In: Rubin DC (ed.) Remembering our past, chapter 3. New York, NY, US: Cambridge University Press, pp. 67-93. DOI:10.1017/ cbo9780511527913.003.

Conway MA and Pleydell-Pearce CW (2000) The construction of autobiographical memories in the selfmemory system. Psychological review 107(2): 261-288. DOI:10.1037/0033-295X.107.2.261.

Cooman RD, Gieter SD, Pepermans R, Jegers M and Acker FV (2009) Development and validation of the Work Effort Scale. European Journal of Psychological Assessment 25(4): 266-273. DOI:10.1027/1015-5759. 25.4.266.

Curtis JN (1915) On psychology as science of selves. The American Journal of Psychology 26(1): 68. DOI: $10.2307 / 1412879$.

Daniel R, Schuck NW and Niv Y (2015) How to divide and conquer the world, one step at a time. Proceedings of the National Academy of Sciences 112(10): 2929-2930. DOI:10.1073/pnas.1500975112.

Daniel S and Sonnentag S (2016) Crossing the borders: The relationship between boundary management, workfamily enrichment and job satisfaction. The International Journal of Human Resource Management 27(4): 407426. DOI:10.1080/09585192.2015.1020826.

Dante A (1996) The Inferno of Dante: A new verse translation. New York, NY, US: Farrar, Straus and Giroux.
Darwin C (1987) On the origin of species, The works of Charles Darwin, volume 16. New York, NY, US: New York University Press.

Davis S (2006) Implied polyphony in the solo string works of J. S. Bach: A case for the perceptual relevance of structural expression. Music Perception: An Interdisciplinary Journal 23(5): 423-446. DOI:10.1525/ mp.2006.23.5.423.

Descartes R (2017) Meditations on First Philosophy in which are demonstrated the existence of God and the distinction between the human soul and body.

Dickman HR (1963) The perception of behavioral units. In: Barker RG (ed.) The stream of behavior: Explorations of its structure \& content, chapter 2. East Norwalk, CT, US: Appleton-Century-Crofts, pp. 23-41. DOI:10.1037/ 11177-002.

Doherty EE and Cwick JM (2016) Unpacking the complexity of life events and desistance: An application of conjunctive analysis of case configurations to developmental and life course criminology. Journal of Developmental and Life-Course Criminology 2(1): 4563. DOI:10.1007/s40865-015-0023-0.

Donahue EM, Robins RW, Roberts BW and John OP (1993) The divided self: Concurrent and longitudinal effects of psychological adjustment and social roles on selfconcept differentiation. Journal of Personality and Social Psychology 64(5): 834-846. DOI:10.1037/0022-3514. 64.5.834.

Duranti A, Ochs E and Schieffelin BB (eds.) (2012) The handbook of language socialization. Chichester, UK: Wiley-Blackwell.

Enz KF and Talarico JM (2015) Forks in the road: Memories of turning points and transitions. Applied Cognitive Psychology 30(2): 188-195. DOI:10.1002/ acp.3176.

Ersche KD, Lim TV, Ward LH, Robbins TW and Stochl J (2017) Creature of habit: A self-report measure of habitual routines and automatic tendencies in everyday 
life. Personality and Individual Differences 116: 73-85. DOI:10.1016/j.paid.2017.04.024.

Farmer A (2010) Order in the closet: Why attire for women lawyers is still an issue. Perspectives 19(2): 4-7.

Fleming L and Waguespack DM (2007) Brokerage, boundary spanning, and leadership in open innovation communities. Organization Science 18(2): 165-180.

Fludernik M (1996) Towards a 'natural' narratology. London, UK: Routledge. ISBN 0415124824.

Friedman WJ (2004) Time in autobiographical memory. Social Cognition 22(5): 591-605. DOI:10.1521/soco.22. 5.591.50766.

Gamble EAM (1915) A defense of psychology as science of selves. Psychological Bulletin 12(5): 194-202. DOI: 10.1037/h0071893.

Gibson JJ (1950) The Perception of the Visual World. Boston, MA, US: Houghton Mifflin.

Gibson JJ (1966) The senses considered as perceptual systems. Boston, MA, US: Houghton Mifflin.

Gibson JJ (1979) The ecological approach to visual perception. Hillsdale, NJ, US: Erlbaum.

Gibson JJ (1986) The ecological approach to visual perception. Hillsdale, NJ, US: Lawrence Erlbaum.

Giles F (2018) Images of women breastfeeding in public: Solitude and sociality in recent photographic portraiture. International Breastfeeding Journal 13(1). DOI:10. 1186/s13006-018-0194-5.

Greenwald AG, Leippe MR, Pratkanis AR and Baumgardner MH (1986) Under what conditions does theory obstruct research progress? Psychological Review 93(2): 216-229.

Grice P (1975) Logic and conversation. In: Cole P and Morgan J (eds.) Syntax and semantics, volume 3: Speech acts. New York, NY US: Academic Pres, pp. 41-58.

Grimaldi DA and Engel MS (2007) Why descriptive science still matters. BioScience 57(8): 646-647. DOI:10.1641/ b570802.
Gurung RAR, Brickner M, Leet M and Punke E (2017) Dressing "in code": Clothing rules, propriety, and perceptions. The Journal of Social Psychology DOI: 10.1080/00224545.2017.1393383.

Hall DT and Richter J (1988) Balancing work life and home life: What can organizations do to help? Academy of Management Perspectives 2(3): 213-223. DOI:10.5465/ ame.1988.4277258.

Hartmann E, Elkin R and Garg M (1991) Personality and dreaming: The dreams of people with very thick or very thin boundaries. Dreaming 1(4): 311-324. DOI:10.1037/ h0094342.

Hawking S (2013) My Brief History. Kindle edition. New York, NY, US: Random House.

Heise G and Miller G (1951) An experimental study of auditory patterns. American Journal of Psychology 64(1): 68-77.

Hindin MJ (2011) Role theory. In: Ritzer G and Ryan JM (eds.) The concise encyclopedia of sociology. Chichester, UK: Wiley-Blackwell, p. 508.

Hintzman DL (2016) Is memory organized by temporal contiguity? Memory \& Cognition 44(3): 365-375. DOI: 10.3758/s13421-015-0573-8.

Hirst W and Phelps EA (2016) Flashbulb memories. Current Directions in Psychological Science 25(1): 3641. DOI:10.1177/0963721415622487.

Hirst W, Phelps EA, Meksin R, Vaidya CJ, Johnson MK, Mitchell KJ, Buckner RL, Budson AE, Gabrieli JDE, Lustig C, Mather M, Ochsner KN, Schacter D, Simons JS, Lyle KB, Cuc AF and Olsson A (2015) A ten-year follow-up of a study of memory for the attack of september 11, 2001: Flashbulb memories and memories for flashbulb events. Journal of Experimental Psychology: General .

Huron D (2006) Sweet anticipation: Music and the psychology of expectation. Cambridge, MA, US: MIT Press. 
Husserl E (1991) On the phenomenology of the consciousness of internal time (1893-1917). In: Bernet R (ed.) Collected works, volume IV. Dordrecht, NL: Kluwer Academic Publishers.

Huys QJM, Lally N, Faulkner P, Eshel N, Seifritz E, Gershman SJ, Dayan P and Roiser JP (2015) Interplay of approximate planning strategies. Proceedings of the National Academy of Sciences 112(10): 3098-3103. DOI:10.1073/pnas.1414219112.

James K and Asmus C (2001) Personality, cognitive skills, and creativity in different life domains. Creativity Research Journal 13(2): 149-159. DOI:10.1207/ S15326934CRJ1302\{\-\}3.

James W (1884) On some omissions of introspective psychology. Mind 9(33): 1-26.

James W (1981) The Principles of Psychology. Cambridge, MA, US: Harvard University Press.

Judge TA, Simon LS, Hurst C and Kelley K (2014) What I experienced yesterday is who I am today: Relationship of work motivations and behaviors to within-individual variation in the five-factor model of personality. Journal of Applied Psychology 99(2): 199-221. DOI:10.1037/ $\mathrm{a} 0034485$.

Kahneman D, Krueger AB, Schkade DA, Schwarz N and Stone AA (2004) A survey method for characterizing daily life experience: The day reconstruction method. Science 306(5702): 1776-1780.

Kahneman D and Miller DT (1986) Norm theory: Comparing reality to its alternatives. Psychological Review 93: 136-153.

Kahneman D and Riis J (2005) Living, and thinking about it: Two perspectives on life. In: Huppert F, Baylis $\mathrm{N}$ and Keverne B (eds.) The science of well-being, chapter 11 . Oxford, UK: Oxford University Press, pp. 285-304.

Kallens PAC, Dale R and Smaldino PE (2018) Cultural evolution of categorization. Cognitive Systems Research 52: 765-774. DOI:10.1016/j.cogsys.2018.08.026.
Kallgren CA, Reno RR and Cialdini RB (2000) A focus theory of normative conduct: When norms do and do not affect behavior. Personality and Social Psychology Bulletin 26(8): 1002-1012. DOI:10.1177/ 01461672002610009.

Kemp S, Burt CDB and Malinen S (2009) Investigating the structure of autobiographical memory using reaction times. Memory 17(5): 511-517. DOI:10.1080/ 09658210902939330.

Kim PH, Ployhart RE and Gibson CB (2018) Editors' comments: Is organizational behavior overtheorized? Academy of Management Review 43(4): 541-545. DOI: 10.5465/amr.2018.0233.

Koenig AM and Eagly AH (2014) Evidence for the social role theory of stereotype content: Observations of groups' roles shape stereotypes. Journal of Personality and Social Psychology 107(3): 371-392. DOI:10.1037/ $\mathrm{a} 0037215$.

Koffka K (1922) Perception: an introduction to the GestaltTheorie. Psychological Bulletin 19(10): 531-585. DOI: $10.1037 / \mathrm{h} 0072422$.

Kraha A, Talarico JM and Boals A (2014) Unexpected positive events do not result in flashbulb memories. Applied Cognitive Psychology 28(4): 579-589.

Kübler A, Winter S, Ludolph AC, Hautzinger $\mathrm{M}$ and Birbaumer N (2005) Severity of depressive symptoms and quality of life in patients with amyotrophic lateral sclerosis. Neurorehabilitation and Neural Repair 19(3): 182-193. DOI:10.1177/1545968305276583.

Kubovy M (1999) On the pleasures of the mind. In: Kahneman D, Diener E and Schwarz N (eds.) Foundations of hedonic psychology: Scientific perspectives on enjoyment and suffering. New York, NY, USA: Russell Sage Foundation, pp. 134-154.

Kubovy M (2015) The deep structure of lives. Philosophiae Scientiae 19(3): 153-176. DOI: 10.4000/philosophiascientiae.1139. 
Labov W (1997) Some further steps in narrative analysis. Oral Versions of Personal Experience 7(1-4): 395-415. DOI:10.1075/jnlh.7.49som.

Labov W (2006) Narrative pre-construction. Narrative Inquiry 16(1): 37-45. DOI:10.1075/ni.16.1.07lab.

Labov W and Waletzky J (1997) Narrative analysis: Oral versions of personal experience. Journal of Narrative and Life History 7(1-4): 3-38. DOI:10.1075/jnlh.7. 02nar.

Lakoff G and Turner M (1989) More than cool reason: A field guide to poetic metaphor. Chicago, IL, US: The University Of Chicago Press.

Lehne $M$ and Koelsch S (2015) Toward a general psychological model of tension and suspense. Frontiers in psychology 6: 79. DOI:10.3389/fpsyg.2015.00079.

Lester D (2017) On multiple selves. Milton Park, Abdingdon, Oxon, UK: Routledge.

Leung K and Morris MW (2015) Values, schemas, and norms in the culture-behavior nexus: A situated dynamics framework. Journal of International Business Studies 46(9): 1028-1050. DOI:10.1057/jibs.2014.66.

Levi P (2015) If this is man. In: Goldstein A (ed.) The complete works of Primo Levi, chapter 1. New York, NY, US: Liveright, pp. 1-206.

Lewin K (1997) Psycho-sociological problems of a minority group (1935). In: Resolving social conflicts (with Field theory in social psychology). Washington, DC: APA, pp. 107-115. DOI:10.1037/10269-009.

Little BR (1983) Personal projects: A rationale and method for investigation. Environment and Behavior 15(3): 273309. DOI:10.1177/0013916583153002.

Little BR (1993) Personal projects and the distributed self: Aspects of a conative psychology. In: Suls JM (ed.) The self in social perspective, chapter 6. Hillsdale, NJ, US: Lawrence Erlbaum, pp. 157-185.

Little BR (1996) Free traits, personal projects and idio-tapes: Three tiers for personality psychology.
Psychological Inquiry 7(4): 340-344. DOI:10.1207/ s15327965pli0704_6.

Little BR (1999a) Personal projects and social ecology: Themes and variations across the life span. In: Brandtstädter J and Lerner RM (eds.) Action \& selfdevelopment: Theory and research through the life span, chapter 7. Thousand Oaks, CA, US: Sage Publications, pp. 197-222. DOI:10.4135/9781452204802.n7.

Little BR (1999b) Personality and motivation: Personal action and the conative evolution. In: Pervin LA and John OP (eds.) Handbook of personality: Theory and research, chapter 20. New York, NY, US: Guilford Press, pp. 501524.

Little BR (2000) Persons, contexts, and personal projects. In: Wapner S, Demick J, Yamamoto $\mathrm{T}$ and Minami $\mathrm{H}$ (eds.) Theoretical perspectives in environment-behavior research: Underlying assumptions, research problems, and methodologies, chapter 8. Boston, MA, US: Springer US. ISBN 978-1-4615-4701-3, pp. 79-88. DOI:10.1007/ 978-1-4615-4701-3_8.

Little BR (2013) Personal projects analysis: Trivial pursuits, magnificent obsessions, and the search for coherence. New York, NY, US: Springer. ISBN 978-1-46840634-4, pp. 15-31. DOI:10.1007/978-1-4684-0634-4_2.

Little BR (2014) Well-doing: Personal projects and the quality of lives. School Field 12(3): 329-346. DOI: $10.1177 / 1477878514545847$.

Little BR, Leccl L and Watkinson B (1992) Personality and personal projects: Linking Big Five and PAC units of analysis. Journal of Personality 60(2): 501-525. DOI: 10.1111/j.1467-6494.1992.tb00982.x.

Lorenz K (1937) Über die Bildung des Instinktbegriffes. Die Naturwissenschaften 25(19): 289-300. DOI:10. 1007/bf01492648.

Lyubomirsky S, Layous K, Chancellor J and Nelson SK (2015) Thinking about rumination: The scholarly contributions and intellectual legacy of Susan NolenHoeksema. Annual Review of Clinical Psychology 11(1): 1-22. DOI:10.1146/annurev-clinpsy-032814-112733. 
Marks SR and MacDermid SM (1996) Multiple roles and the self: A theory of role balance. Journal of Marriage and the Family 58(2): 417. DOI:10.2307/353506.

Matson JL (ed.) (2017) Clinical guide to toilet training children. Autism and Child Psychopathology Series. Cham, CH: Springer. ISBN 3319627244.

McConnell AR, Shoda TM and Skulborstad HM (2012) The self as a collection of multiple self-aspects: Structure, development, operation, and implications. Social Cognition 30(4): 380-395. DOI:10.1521/soco. 2012.30.4.380.

Meehl PE (1956) Wanted-a good cook-book. American Psychologist 11(6): 263-272. DOI:10.1037/h0044164.

Merton RK (1961) Singletons and multiples in scientific discovery: A chapter in the sociology of science. Proceedings of the American Philosophical Society 105(5): 470-486.

Miller GA and Heise GA (1950) The trill threshold. Journal of the Acoustical Society of America 22: 637-638.

Mischel W (2004) Toward an integrative science of the person. Annual Review of Psychology 55(1-22). DOI: 10.1146/annurev.psych.55.042902.130709.

Mischel W and Shoda Y (1995) A cognitive-affective system theory of personality: Reconceptualizing situations, dispositions, dynamics, and invariance in personality structure. Psychological Review 102(2): 246-268. DOI: 10.1037/0033-295x.102.2.246.

Mischel W and Shoda Y (2010) The situated person. In: Mesquita B, Barrett LF and Smith ER (eds.) The Mind in Context, chapter 8. New York, NY, US: The Guilford Press, pp. 149-173.

Moisset X, Cornut-Chauvinc C, Clavelou P, Pereira B, Dallel R and Guy N (2015) Is there pain with neuropathic characteristics in patients with amyotrophic lateral sclerosis? A cross-sectional study. Palliative Medicine 30(5): 486-494. DOI:10.1177/0269216315600332.

Mondol AS, Ra HK, Salekin A, Yoon HJ, Kubovy M, Son SH and Stankovic JA (2016) LifeMaps: An automated diary system based on the structure of lives. In: Proceedings of the 14th ACM Conference on Embedded Network Sensor Systems CD-ROM, SenSys '16. New York, NY, US: ACM. ISBN 978-1-4503-4263-6, pp. 348-349. DOI:10.1145/2994551.2996700.

Nelson RR and Winter SG (1985) An evolutionary theory of economic change. Belknap Press. ISBN 0674272285.

Newtson D (1976) Foundations of attribution: The perception of ongoing behavior. In: Harvey JH, Ickes WJ and KJdd RF (eds.) New Directions in Attribution Research, volume I. Erlbaum, pp. 223-247.

Newtson D, Hairfield J, Bloomingdale $\mathrm{J}$ and Cutino $\mathrm{S}$ (1987) The structure of action and interaction. Social Cognition 5(3): 191-237.

Nippert-Eng CE (1996) Home and work: Negotiating boundaries through everyday life. Chicago, IL, US: University of Chicago Press.

Nippert-Eng CE (2008) Home and work: Negotiating boundaries through everyday life. Chicago, IL, US: University of Chicago Press.

Nordfjærn T, Şimşekoğlu Ö and Rundmo T (2014) The role of deliberate planning, car habit and resistance to change in public transportation mode use. Transportation Research Part F: Traffic Psychology and Behaviour 27: 90-98. DOI:10.1016/j.trf.2014.09.010.

Norrick NR (2005) The dark side of tellability. Narrative Inquiry 15(2): 323-343.

Oeser OA and Harary F (1962) A mathematical model for structural role theory, I. Human Relations 15: 89-109.

Oeser OA and Harary F (1964) A mathematical model for structural role theory, II. Human Relations 17: 3-17.

Ohl M (2018) The Art of Naming. Cambridge, MA, US: MIT Press.

O’Toole G (2015) All science is either physics or stamp collecting. Quote Investigator blog. 
Pachucki MA, Pendergrass S and Lamont M (2007) Boundary processes: Recent theoretical developments and new contributions. Poetics 35(6): 331-351. DOI: 10.1016/j.poetic.2007.10.001.

Palmier-Claus J, Haddock G and Varese F (eds.) (2019) Experience sampling in mental health research. London, UK: Routledge.

Parks L and Guay RP (2009) Personality, values, and motivation. Personality and Individual Differences 47(7): 675-684. DOI:https://doi.org/10.1016/j.paid.2009.06. 002.

People are Awesome (2015) Fast workers edition. URL https://goo.gl/qTLhWQ.

Piaget J (1924) Le jugement et le raisonnement chez l'enfant. Geneva, CH: Delachaux et Niestlé.

Pillemer DB (2009) Momentous events, vivid memories. Cambridge, MA, US: Harvard University Press.

Polkinghorne DE (1988) Narrative knowing and the human sciences. State University of New York. ISBN 0887066232.

Pöppel E (2004) Lost in time: A historical frame, elementary processing units and the 3-second window. Acta Neurobioliga Experimentalis 64: 295-301.

Postill J (2002) Clock and calendar time. Time \& Society 11(2-3): 251-270. DOI:10.1177/ $0961463 \times 02011002005$.

Pratt MG, Schultz M, Ashforth BE and Ravasi D (eds.) (2016) The Oxford Handbook of Organizational Identity. Oxford, UK: Oxford University Press. DOI:10.1093/ oxfordhb/9780199689576.001.0001.

Quinn N (2003) Cultural selves. Annals of the New York Academy of Sciences 1001(1): 145-176. DOI:10.1196/ annals.1279.010.

Quinn N and Mathews HF (2016) Emotional arousal in the making of cultural selves. Anthropological Theory 16(4): 359-389. DOI:10.1177/1463499616684051.
Quintelier E (2013) Engaging adolescents in politics. Youth \& Society 47(1): 51-69. DOI:10.1177/ $0044118 \times 13507295$.

Radvansky GA and Zacks JM (2017) Event boundaries in memory and cognition. Current Opinion in Behavioral Sciences 17: 133-140. DOI:10.1016/j.cobeha.2017.08. 006. Part of special issue on Memory in time and space.

Richmond LL and Zacks JM (2017) Constructing experience: Event models from perception to action. Trends in Cognitive Sciences 21(12): 962-980. DOI: 10.1016/j.tics.2017.08.005.

Roberts JA and Clement A (2006) Materialism and satisfaction with over-all quality of life and eight life domains. Social Indicators Research 82(1): 79-92. DOI: 10.1007/s11205-006-9015-0.

Robins JM (2017) Phrase structure, hypermeter, and closure in popular music. $\mathrm{PhD}$ Thesis, Florida State University, Tallahassee, FL, US. ProQuest No. 10262010.

Rosch E (1978) Principles of categorization. In: Rosch E and Lloyd B (eds.) Cognition and Categorization, chapter 3. Hillsdale, NJ, US: Lawrence Elbaum Associates, pp. 27-48.

Rosen C (1972) The classical style: Haydn, Mozart, Beethoven. Norton edition. New York, NY, US: Norton.

Rubin DC and Greenberg DL (2003) The role of narrative in recollection: A view from cognitive psychology and neuropsychology. In: Fireman GD, McVay TE and Flanagan OJ (eds.) Narrative and consciousness : Literature, psychology and the brain, chapter 4. Cary, NC, US: Oxford University Press, pp. 53-85.

Rubin E (1915) Synsoplevede Figurer: Studier i psykologisk Analyse. Copenhagen, DK: Gyldendalske Boghandel. Rubin's doctoral thesis, unnoticed until his German translation: Rubin, 1921.

Rubin E (1921) Visuell wahrgenommene Figuren: Studien in psychologischer Analyse. Copenhagen, DK: Gyldendalske Boghandel. Excerpt translated into English: Rubin, 1958. 
Rubin E (1958) Figure and ground. In: Beardslee DC and Wertheimer M (eds.) Readings in Perception. Princeton, NJ: D. Van Nostrand, pp. 194-203. This excerpt translated from Rubin, 1921.

Rummel J and McDaniel MA (eds.) (2019) Prospective memory. Abingdon, UK: Routledge.

Saint Augustine of Hippo (1997) Confessions. Hyde Park, NY, US: New City Press.

Salvucci DD and Taatgen NA (2008) Threaded cognition: An integrated theory of concurrent multitasking. Psychological Review 115(1): 101-130. DOI:10.1037/ 0033-295x.115.1.101.

Scerri E and Restrepo G (eds.) (2018) Mendeleev to Oganesson: A multidisciplinary perspective on the periodic table. New York, NY, US: Oxford Universaity Press.

Schafer R (1992) Retelling a life: Narration and dialogue in psychoanalysis. New York, NY, US: Basic Books.

Schank R and Abelson R (1977) Scripts, plans, goals and understanding: An inquiry into human knowledge structures. Hillsdale, NJ, US: Lawrence Erlbaum.

Schütze CT (2016) The empirical base of linguistics: Grammaticality judgments and linguistic methodology. 2 edition. Berlin, DE: Language Science Press.

Schwartz SH, Cieciuch J, Vecchione M, Davidov E, Fischer R, Beierlein C, Ramos A, Verkasalo M, Lönnqvist JE, Demirutku K, Dirilen-Gumus O and Konty M (2012) Refining the theory of basic individual values. Journal of Personality and Social Psychology 103(4): 663-688. DOI:10.1037/a0029393.

Seifert CM and Patalano AL (1991) Memory for incomplete tasks: A re-examination of the Zeigarnik effect. In: McMillan C, Mozer M and Smolensky P (eds.) Proceedings of the Thirteenth Annual Conference of the Cognitive Science Society. Cognitive Science Society, Mahwah, NJ, US: Erlbaum, pp. 114-119.

Sherif M (1936) The psychology of social norms. New York, NY, US: Harper \& Brothers.
Shi L (2017) Transition theory: Evidence from personal transitions and their role in the contents and organization of autobiographical memories. $\mathrm{PhD}$ Thesis, University of Alberta.

Shklovsky V (1965) Art as technique. In: Lemon LT and Reis MJ (eds.) Russian formalist criticism, chapter 2. Lincoln, NE, US: University of Nebraska Press, pp. 814.

Showers CJ (1992) Compartmentalization of positive and negative self-knowledge: Keeping bad apples out of the bunch. Journal of Personality and Social Psychology 62(6): 1036-1049. DOI:10.1037/0022-3514.62.6.1036.

Showers CJ, Ditzfeld CP and Zeigler-Hill V (2015) Selfconcept structure and the quality of self-knowledge. Journal of Personality 83(5): 535-551. DOI:10.1111/ jopy. 12130 .

Showers CJ and Zeigler-Hill V (2007) Compartmentalization and integration: The evaluative organization of contextualized selves. Journal of Personality 75(6): 1181-1204. DOI:10.1111/j.1467-6494.2007.00472.x.

Sieben I (2017) Child-rearing values: The impact of intergenerational class mobility. International Sociology 32(3): 369-390. DOI:10.1177/0268580917693954.

Simmel G (2002) The metropolis and mental life. In: Bridge $\mathrm{G}$ and Watson $\mathrm{S}$ (eds.) The Blackwell city reader, chapter 1. Oxford, UK: Wiley-Blackwell, pp. 11-19.

Simon HA (1962) The architecture of complexity. Proceedings of the American Philosophical Society 106(6): 467-482. DOI:10.1080/14759550302804.

Simon HA (1994) Near decomposability and complexity: How a mind resides in a brain. In: Morowitz HJ and Singer JL (eds.) The mind, the brain, and complex adaptive systems, Santa Fe Institute Studies in the Sciences of Complexity, volume XXII, chapter 3. Boulder, CO, US: Westview Press.

Simon HA (1999) The sciences of the artificial. 3rd edition. Cambridge, MA, US: MIT Press. 
Slepian ML, Ferber SN, Gold JM and Rutchick AM (2015) The cognitive consequences of formal clothing. Social Psychological and Personality Science 6(6): 661-668. DOI:10.1177/1948550615579462.

Smallwood J and Schooler JW (2015) The science of mind wandering: Empirically navigating the stream of consciousness. Annual Review of Psychology 66(1): 487518.

Smith W (2015) A memoir to the map and Delineation of the Strata of England and Wales with part of Scotland. Keyworth, UK: British Geological Survey.

Snygg D (1941) The need for a phenomenological system of psychology. Psychological Review 48(5): 404-424. DOI: $10.1037 / \mathrm{h} 0059710$.

Snygg D (1949) Predicting the behavior of individuals. Canadian Journal of Psychology/Revue canadienne de psychologie 3(1): 19-29. DOI:10.1037/h0084078.

Snygg D and Combs AW (1949) Individual Behavior. A new frame of reference for psychology. New York, NY, US: Harper.

Spence KW (1944) The nature of theory construction in contemporary psychology. Psychological Review 51(1): 47-68. DOI:10.1037/h0060940.

Spinelli M, Fasolo M, Tagini A, Zampini L, Suttora C, Zanchi P and Salerni N (2015) Linguistic and prosodic aspects of child-directed speech: The role of maternal child-rearing experiences. European Journal of Developmental Psychology 13(2): 183-196. DOI: 10.1080/17405629.2015.1080159.

Svob C and Brown NR (2012) Intergenerational transmission of the reminiscence bump and biographical conflict knowledge. Psychological Science 23(11): 1404-1409. DOI:10.1177/0956797612445316.

Taylor H (2017) Is birdsong music? Outback encounters with an Australian songbird. Bloomington, IN, US: Indiana University Press.

Tiersma PM (2000) Legal Language. Chicago, IL, US: University of Chicago Press. ISBN 0226803031.
Tinbergen N (1939) The behavior of the Snow Bunting in spring. Transactions of the Linnaean Society of New York 5 .

Turner RH (2001) Role theory. In: Turner JH (ed.) Handbook of Sociological Theory, chapter 12. Boston, MA, US: Springer Science, pp. 233-254.

Tzeng OJ and Cotton B (1980) A study-phase retrieval model of temporal coding. Journal of Experimental Psychology: Human Learning \& Memory 6(6): 705-716. DOI:10.1037/0278-7393.6.6.705.

Uschold M and Gruninger M (1996) Ontologies: Principles, methods and applications. Knowledge Engineering Review 11(2): 93-136. DOI: 10.1017/S0269888900007797.

Uzer T and Brown NR (2015) Disruptive individual experiences create lifetime periods: A study of autobiographical memory in persons with spinal cord injury. Applied Cognitive Psychology 29(5): 768-774. DOI:10.1002/ acp.3148.

van Noorden LPAS (1971a) Discrimination of time intervals bounded by tones of different frequencies, volume 6. Eindhoven, NL: IPO, pp. 12-15.

van Noorden LPAS (1971b) Rhythmic fission as a function of tone rate, volume 6. Eindhoven, NL: IPO, pp. 9-12.

van Noorden LPAS (1975) Temporal coherence in the perception of tone sequences. $\mathrm{PhD}$ Thesis, Technische Hogeschool Eindhoven, Eindhoven, NL. DOI:10.6100/ IR152538.

von Uexküll J (1909) Umwelt und Innenwelt der Tiere. Berlin, DE: Julius Springer.

Wagemans J, Elder JH, Kubovy M, Palmer SE, Peterson MA, Singh M and von der Heydt R (2012) A century of Gestalt psychology in visual perception: I. Perceptual grouping and figure-ground organization. Psychological Bulletin 138(6): 1172-1217. DOI:10.1037/a0029333.

Wagenaar WA (1986) My memory: A study of autobiographical memory over six years. Cognitive Psychology 18(2): 225-252. DOI:10.1016/0010-0285(86)90013-7. 
Wallace K (2015) Brutally honest: Is it OK to be naked in front of your kids? CNN.com .

Weber M (1946) Science as a vocation. In: Gerth H and Mills CW (eds.) From Max Weber: Essays in sociology. New York, NY, US: Oxford University Press, pp. 129156.

Wertheimer M (1912) Experimentelle Studien über das Sehen von Bewegung. Zeitschrift für Psychologie 61(1): 161-265.

Zacks JM and Tversky B (2001) Event structure in perception and conception. Psychological Bulletin 127: 3-21. DOI:10.1037//0033-2909.127.1.3.

Zeigarnik B (1927) Das Behalten von erledigten und unerledigten Handlungen. Psychologische Forschung 9: $1-85$.

Zeigarnik B (2016) Das Behalten von erledigten und unerledigten Handlungen. In: Metz-Göckel H (ed.) Gestalttheorie und kognitive Psychologie. Wiesbaden, DE: Springer, pp. 131-137.

Zerubavel E (1991) The fine line: Making distinctions in everyday life. New York, NY, US: The Free Press. ISBN 0029344204.

Zerubavel E (1996) Lumping and splitting: Notes on social classification. Sociological Forum 11(3): 421-433. DOI: 10.1007/bf02408386.

Zerubavel E (2015) Figure and background. In: Hidden in plain sight: The social structure of irrelevance, chapter 2. Oxford, UK: Oxford University Press. ISBN 0199366608, pp. 11-25. DOI:10.1093/acprof:oso/ 9780199366606.001.0002.

Zerubavel E (2016) The five pillars of essentialism: Reification and the social construction of an objective reality. Cultural Sociology 10(1): 69-76. DOI:10.1177/ 1749975515616905.

Zhu MJH and Risko EF (2016) Spatial habit competes with effort to determine human spatial organization. Quarterly Journal of Experimental Psychology 69(7): 1255-1264. DOI:10.1080/17470218.2016.1158301.
Zilber TB, Tuval-Mashiach R and Lieblich A (2008) The embedded narrative: Navigating through multiple contexts. Qualitative Inquiry 14(6): 1047-1069. 